\title{
Colonial Fantasy Shattered, Cosmopolitan Dream Broken: V.S. Naipaul's Mr Stone and the Knights Companion
}

\author{
Weiwei Xu \\ College of International Studies, Southwest University \\ 2 Tiansheng Road, Chongqing 400715, China \\ E-mail: xuww1125@163.com
}

Received: 01-06-2015

Published: 01-01-2016
Accepted: 17-09-2015

doi:10.7575/aiac.ijalel.v.5n.1p.106
Advance Access Published: October 2015

URL: http://dx.doi.org/10.7575/aiac.ijalel.v.5n.1p.106

The research is financed by Chongqing Social Science Planning Fund Program. No. $2014 Q N W X 30$ and The Fundamental Research Funds for the Central Universities. No. SWU1509173, SWU1409348.

\begin{abstract}
V. S. Naipaul's depiction of the dull London life in $\mathrm{Mr}$ Stone and the Knights Companion challenges metropolitancentrism in cosmopolitanism. Criticising the self-consciousness and insularity of English people, Naipaul illustrates the point that the multiplication of cultural contacts and exchanges facilitated in the metropolis does not necessarily mean that the metropolitan locals exposed to it are pre-disposed toward cosmopolitan openness. He also points out the allure and danger of cosmopolitanism: consumption of various cultural products and luxurious stylisation of metropolitan life are superficially understood as signals of access and openness to differences, while xenophobia toward immigrants lurking under such a consumer orientation.
\end{abstract}

Keywords: colonial fantasy, metropolis, cosmopolitanism

\section{Introduction}

The metropolis is conventionally viewed as the site where cosmopolitanism is created and located, and its economic and cultural dominance becomes central to cosmopolitan imagination. Mike Featherstone (2002), for instance, points out that "cosmopolitan dispositions are closely associated with cities", more importantly with Euro-American metropolises such as London, Paris and New York, since they have long been "the sites for markets and the mixing of people, commodities, ideas and cultures" and "the homes of a wide range of intellectual and artistic social and cultural movements and institutions" (p. 1-2). Gary Bridge (2005) posits: "It is in the burgeoning transnational neighbourhoods of the global cities that the best prospects of cosmopolitanism are to be found: cosmopolitanism as a form of reason lived daily in the city of difference." (p. 158) Leonie Sandercock (2006) argues for "a cosmopolitan urbanism as a normative project that is a necessary response to the empirical reality of multicultural cities" (p. 39). Mica Nava (2007) further suggests that cosmopolitanism is "an ordinary everyday aspect of metropolitan UK culture" (p. 134). The typical cultural form of the metropolis is cosmopolitanism understood as an exposure to a mix of many kinds of cultural and social frames of reference, thanks to which the individual has the simultaneous experience of both proximity and distance.

However, metropolitan-centrism in cosmopolitan theory - the elitist, normative conception that metropolitan culture is a prerequisite for cosmopolitan imagination-has been challenged and refuted. On the one hand, cosmopolitanism identified with the metropolis can quite easily become synonymous with a kind of urban sophistication, and cosmopolitan possibilities are classed, gendered or racialised. Tim Butler describes how White, middle-class gentrifiers in north London appropriate a discourse of belonging that accentuates and celebrates diversity, whilst their lives in practice are characterised by social exclusivity. The cosmopolitan is thus presented as White and middle-class, standing out in a multiethnic metropolis because of their whiteness. Butler (2003) concludes that despite their "long rhetorical flushes in favour of multiculturalism and diversity" (p. 2469), White and middle-class residents of north London regard ethnic minorities as "a kind of social wallpaper" (Butler, 2003, p. 2484). They do not engage with the dialectical or transformative process that a cosmopolitan ethos entails; instead, their "metropolitan habitus —of feelings, attitudes and beliefs" transforms the metropolis into "the natural habitat for a section of the new (urban-seeking) middle classes" (Butler, 2003, p. 2484). On the other hand, the cosmopolitan experience of individuals in the metropolis (especially immigrants) cannot be equated with the cosmopolitan nature of the city. Daniel Hiebert draws on his study of transnational communities in Vancouver to illustrate that transnational connections and exchanges in themselves do not necessarily foster cosmopolitanism amongst labour migrants or elite professionals. Hiebert (2002) even contends: "In fact, in certain cases transnational lifestyles may actually inhibit cosmopolitanism." (p. 210) Ranji Devadason reaches a similar conclusion in her analysis of the extent to which London engenders cosmopolitan values amongst its established minorities and ethnic majority. Devadason (2010) reminds us: "Cosmopolitanism is not something which can be 
inferred from diversity in itself; it requires transformation in "structures of meaning" both for the individual and the political community." (p. 2960)

Mr Stone and the Knights Companion (1963), V. S. Naipaul's only novel set entirely in London, dealing with exclusively English characters, is the ideal text to examine how the postcolonial writer imagines and constructs the metropolis. I would argue that Naipaul's earlier colonial fantasy that cosmopolitanism only exists in the metropolis and is accessible to the privileged individuals is severely shattered.

\section{Colonial Fantasy Shattered}

\subsection{The Dull London Life}

When he was still at work on A House for Mr Biswas (1961), Naipaul narrated how he experienced London in his essay "London". He emphasises his sense of being continually excluded from London, because "everything goes on behind closed doors" (Naipaul, 1972, p. 14) there. His engagement with London seems spoiled by his inability to penetrate beneath its surfaces and to discover the substance of London life. Naipaul admits that his knowledge of London and of England remains profoundly unsatisfactory: "I feel I know so little about England. I have met many people but I know them only in official attitudes - the drink, the interview, the meal. I have a few friends. But this gives me only a superficial knowledge of the country, and in order to write fiction it is necessary to know so much: we are not all brothers under the skin." (Naipaul, 1972, p. 14) Describing several nights out at the restaurant, nightclub and theatre, which end with him lonely, looking for a bus, haunted by a sense of disappointment and waste, he complains about the depressing "privacy of the big city" and the lack of "communal pleasures" (Naipaul, 1972, p. 15). He confesses: "But after eight years here I find I have, without effort, achieved the Buddhist ideal of non-attachment. I am never disturbed by national or international issues. I do not sign petitions. I do not vote. I do not march. And I never cease to feel that this lack of interest is all wrong. I want to be involved, to be touched even by some of the prevailing anger." (Naipaul 1972, p. 16) Naipaul concludes the essay by recording the "barrenness" of his life in London and the impact it might have on his imaginative faculties: "Unless I am able to refresh myself by travel— to Trinidad, to India—I fear that living here will eventually lead to my own sterility; and I may have to look for another job." (Naipaul, 1972, p. 16)

$\mathrm{Mr}$ Stone and the Knights Companion shows that Naipaul tries to register his self-consciously peripheral engagement with the metropolis and sense of being defrauded by and displaced from its substance. At first glance, Naipaul's earlier characters in the steaming, chaotic Trinidad would be literally unimaginable in Mr Stone's cool, ordered world of middle-class London respectability. For the boy narrator of Miguel Street, for Ganesh and for Mr Biswas, London and England epitomise civility and order, the fountainhead of all inspirations. Mr Stone possesses all that is desirable to them - a house of his own in suburban London, a steady and respectable job, and a pension after his retirement. Whereas the image of the house in A House for Mr Biswas is frequently used to convey the disorder, haphazardness and transience of Trinidad, Mr Stone's house is a much more substantial affair, a regulated space that happily records a long history of occupancy. Mr Stone takes pleasure "in the slow decay of his own house, the time-created shabbiness of its interiors, the hard polish of old grime on the lower areas of the hall wallpaper, feeling it right that objects like houses should age with their owners and carry marks of their habitation" (Naipaul, 1963, p. 22). His well-ordered life, upon which he reflects with some frequency, is a source of satisfaction: "Mr Stone liked to think in numbers. He liked to think, 'I have been with Excal for thirty years.' He liked to think, 'I have been living in this house for twenty-four years.' He liked to think of the steady rise of his salary, since he had gone into industry, to its present $£ 1,000$ a year; and he liked to think that by earning this sum he was in the top five per cent of the country's wage-earners (he had read this fact somewhere, possibly in the Evening Standard). He liked to think he had known Tomlinson for forty-four years." (Naipaul, 1963, p. 18)

Mr Stone enjoys his rootedness in the milieu of middle-class London suburbia. The financial and social security into which he was born is supported by and contributes to a highly stable society with a set of dependable norms and rights, a coherent culture, and an accessible history. His surname "Stone" perfectly suggests the "solidity, continuity and flow" (Naipaul, 1963, p. 20) not only of his own ready-made identities and positions, but also of the grandeur of London and England.

Nevertheless, Naipaul presents Mr Stone's life as insular and dull, "possibly the price of order in a well-regulated society" (Mustafa, 1995, p. 91), to acknowledge and unravel his assumption of the "perfection" of the metropolis. At the opening of the novel, Mr Stone is introduced as an old bachelor with few attachments. He only briefly visits his widowed sister Olive who provides him with female attention after their mother died when he was seventeen, while fixing his "distaste" (Naipaul, 1963, p. 28) for Olive's daughter Gwen. He has a friend with whom he "annually renewed" (Naipaul, 1963, p. 10) the friendship, a housekeeper with whom he barely communicates, and a few colleagues with whom he has "only an office relationship" (Naipaul, 1963, p. 47). He even refuses to "bid anyone on it [the street where Mr Stone lives] good-day for fear that such greeting might be imposed on him in perpetuity, leading to heaven knows what intimacy" (Naipaul, 1963, p. 36). Mr Stone purely cultivates and is strict with his never-rushed habitual actions, which border on dreary routines. He always shaves the right side of his face first, and puts on his right shoe first. He reads the first page and no more of the Telegraph at breakfast, and buys two evening newspapers from a particular vendor at Victoria to read at leisure after dinner, not on the train. He does not even savour the news, for he instantly forgets most of what he reads. He treats it "as part of a newspaper, something which day by day produced itself for his benefit during this after-dinner period, an insulation against the world out of which it arose" (Naipaul, 1963 , p. 20). In the office, he recognises the days of the week from the regular changing of his assistant's business outfits. At home, his housekeeper Miss Millington shops every Thursday morning and goes to the cinema every 
Thursday afternoon. The only thing that intrudes upon his settled existence is his neighbour's cat, a creature of free will. Its daily "obscene scuttlings and dredgings and buryings" (Naipaul, 1963, p. 6) on his flowerbeds require frequent reparations. Armed with cat pepper, Mr Stone is at war with it. "Stone", in fact, symbolises the rigid, ossified order. Finding himself living a drab life in London, Naipaul makes Mr Stone's insular, ritualistic existence a story that "we have come to associate with the English provinces after the war, when English writing turned inward from larger issues and was fascinated by the manners, morals and lives of the drab rather than the sophisticated and cosmopolitan" (King, 2003, p. 62).

\subsection{Post-War London Transformed by Immigrants}

The shadow of the war still hangs implicitly over England in Mr Stone and the Knights Companion. Mr Stone realises that "he was surrounded by women-Margaret, Grace, Olive, Gwen, Miss Millington — and that these women all lived in a world of dead or absent men" (Naipaul, 1963, p. 131). If the Knights Companion scheme that he creates for the welfare of the retired is "for the protection of the impotent male" (Naipaul, 1963, p. 84), the post-war Empire in terminal decline is just like that male. It is not only substantially ruined by the ravages of the war, but also ultimately transformed by its immigrant communities as a result of exultant decolonisation movements around the world. Toward the end of the first chapter of the novel, Mr Stone goes to visit Margaret Springer whom he is soon to marry:

Mrs Springer lived in Earl's Court. A disreputable, overcrowded area Mr Stone had always thought it, and he thought no better of it now. The entrance to the Underground station was filthy; in a street across the road a meeting of the British National Party was in progress, a man shouting himself hoarse from the back of a van. Behind neon lights and streaming glass windows the new-style coffee houses were packed; and the streets were full of young people in art-student dress and foreigners of every colour. (Naipaul, 1963, p. 32)

The visible ethnic pluralism and cultural admixture incubating in post-war London are indicators of cosmopolitanism as "a socio-cultural condition" (Vertovec \& Cohen, 2002, p. 9) linked to large-scale migration, which facilitates a multiplication of cultural contacts and social exchanges bringing the English closer to other physically and psychologically distant cultures. John McLeod interprets Naipaul's depiction of Earl's Court as "the shattered colonial fantasy of decorum and the disturbing muddle of contemporary, cosmopolitan London-where the certainties of English place are challenged by the spontaneous and contingent transformations of subaltern renegotiations of space" (McLeod, 2004, p. 71). In other words, elements that used to be marginal or peripheral with respect to those dominant ones now express the formation of a cosmopolitan culture in the metropolis. Naipaul may not celebrate the positive dimension of cosmopolitanism that politically and socially challenges ethnocentric or national narratives, but it would be over-simplistic to interpret it as his nostalgic longing for a homogeneous, pure English culture. He points up here that the opening-up of the political-social space of the metropolis cannot necessarily cultivate an open, cosmopolitan vision among the metropolitan locals who, in fear of the death of their local and national identities, shun others. As Craig Calhoun (2002) has argued, "while cities can be places of creative disorder, jumbling together ethnicities, classes, and political projects, most people claim only familiar parts of the diversity on offer" (p. 104). Mr Stone obviously carries a general dislike of the coloured immigrants infiltrating into Earl's Court, "a symbol of a nascent multiracial society beginning to impinge on the homogeneous, older England Mr. Stone represents" (Thieme, 1984, p. 499-500). The new, heterogeneous urban populace contributes to making London's physicality that does not necessarily square with, even betrays, the promise of English order, which guarantees continuity between England's past and present, its colonial possessions overseas and metropolitan heart. To Mr Stone, cosmopolitanism assumes a threatening dissolution of his identity. Mr Stone is only reassured to find out that the private hotel off the Earl's Court Road where Margaret lives appears to be a bastion against incursions - "a small typewritten 'Europeans Only' card below the bell proclaimed it a refuge of respectability and calm" (Naipaul, 1963, p. 32). The ignorance of the surrounding demographic change and smooth retreat into white supremacy (an almost fascist proclamation of national and racial exclusiveness) articulate the irony of the author, himself a coloured immigrant depressed by the impenetrability of the metropolis.

\section{Cosmopolitan Dream Broken}

\subsection{Travel, Cosmopolitan Curiosity and English Insularity}

In $\mathrm{Mr}$ Stone and the Knights Companion, Naipaul adopts an overall cool voice with detached irony to criticise the conservatism and cultural remoteness of Englishness and the insularity of the English. Englishness becomes selfpossessed, even ignorant, since the English, who have difficulty in getting over "the barrier of self-consciousness" (Naipaul, 1972, p. 15) in their activities and responses, withdraw into themselves rather than look outwards. This is most evident in their contacts with other cultures through travel. A common feature of cosmopolitanism is the lionisation of travel as the key to self-enhancement and the cultivation of a sophisticated, worldly outlook. In the words of Barry Curtis and Claire Pajaczkowska (1994), travel implies "a journey of metamorphosis and transformation, in which the self is changed by the experience of alterity encountered in a dialectic of difference" (p. 206). Calhoun (2002) points out that "cosmopolitanism has considerable rhetorical advantage", because "it seems hard not to want to be a "citizen of the world"" (p. 89) when exposed to other geographies and cultures through travel.

Nonetheless, Naipaul suggests that travel does not necessarily lead to a greater level of cosmopolitanism, which is supposed to be marked by an open stance toward difference and an inclusive consciousness. Ulf Hannerz (1990) points out that "we often use the term 'cosmopolitan' rather loosely, to describe just about anybody who moves about in the world" (p. 238). Rosabeth Moss Kanter (1995) also warns us that "it is not travel that defines cosmopolitans-some 
widely traveled people remain hopelessly parochial-it [cosmopolitanism] is mind-set" (p. 23). In contrast to Naipaul's earlier Trinidadian characters who have no chance to travel at home or abroad, the English characters in $\mathrm{Mr}$ Stone and the Knights Companion enjoy the privilege conferred by the dominant power of their country to travel anywhere of their free will, even in a luxurious style. But unfortunately, they do not move mentally or psychologically. We are told that "Mr Stone preferred to spend his holidays in England. He had thought after the war that he would go abroad. In 1948 he went to Ireland; but the most enjoyable part of that holiday was the journey from Southampton to Cobh in a luxurious, rationing-free American liner" (Naipaul, 1963, p. 60). When Mr Stone describes this journey to Gwen, Olive comments that it is "too self-conscious and namby-pamby" (Naipaul, 1963, p. 148). Travelling in Paris, Mr Stone does not display an appreciation for the French cultural milieu into which he is inserted, and all that is left in his head is unpleasant memory:

A fortnight in Paris two years later had been, after the first moment of pleasure at being in the celebrated city, a tedious torment. He had dutifully gone sightseeing and had been considerably fatigued; he often wondered afterwards why he followed the guidebook so slavishly and went to places as dreary as the Pantheon and the Invalides. He had sat in the cafes, but hated the coffee, and to sit idling in an unfamiliar place was not pleasant, and the cups of coffee were so small. He had tried aperitifs but had decided they were a waste of time and money. He was very lonely; his pocket was playfully picked by an Algerian, who warned him to be more careful in future; everything was hideously expensive; the incessant cries from men and women of le service, monsieur, le service! had given him a new view of the French, who he had thought a frivolous, fun-loving people made a little sad by the war. And for the last two days he was afflicted by a type of dysentery which made it impossible for him to take anything more solid than mineral water. (Naipaul, 1963, p. 60-61)

Similarly, Grace Tomlinson's trip to Paris, "not surprisingly", gives her "little pleasure" (Naipaul, 1963, p. 130). In a metropolis like Paris where cosmopolitanism is ideally marked by people's appreciation for cultural diversities and exchanges, the close-mindedness of Mr Stone and Grace is accentuated. Naipaul implicitly makes the point in the novel that the metropolis does not necessarily foster cosmopolitanism, that people's open, cosmopolitan outlook should be the key to therapy for parochialism. Failing to shed the bias of their own home culture, Naipaul's English characters in $\mathrm{Mr}$ Stone and the Knights Companion are really what Hannerz (1990) calls "anti-cosmopolitans...people who are locals at heart" (p. 241), who see and judge anything in other parts of the world as a kind of evil contamination through their local, parochial lens. Lacking the deeper curiosity about the world outside the self, they become the counter-image of Naipaul, who alludes to an enjoyment of "the experience of travel and human discovery for its own sake" as it "broadened my world view; it showed me a changing world, and took me out of my own colonial shell" (Naipaul, 1985, p. 11-12). Naipaul implies that insularity strangles the English's capacity to look at the world with the possibility of cultural diversity. Their unwillingness to pay a necessary cost to get involved with other European cultures shows their hidden assumption about the ranking of cultures, in which only English culture stands at the top of the pyramid. It is unimaginable how they would rank other marginal, subaltern cultures. Whereas the Trinidadian insularity in Naipaul's first four novels is about inferiority and self-abasement under the intimidation of colonialism, the English insularity presented in $\mathrm{Mr}$ Stone and the Knights Companion is about self-consciousness and arrogance.

\subsection{The Hegemonic, Fraudulent Metropolitan Culture}

At the same time, Naipaul is aware of the prevalent, dangerous homogenising power of the English insular parochialism intolerant of difference. In $\mathrm{Mr}$ Stone and the Knights Companion, a Jamaican family move into Mr Stone's neighbourhood. Their intrusion into the territory of middle-class London suburbia (like the presence of foreigners in Earl's Court) indicates that the metropolis begins to look like a mosaic. Yet, it is not very cosmopolitan. The Jamaican family try to demonstrate their "ferocious respectability" by receiving "no negro callers", accepting "no negro lodgers for the room they let", keeping a budgerigar, and having their house repainted by English decorators until "its gleaming black-pointed red brick was like a reproach to the rest of the street" (Naipaul, 1963, p. 140). Here, Naipaul presents the hegemonic nature of the metropolitan culture. As long as England's cultural universalisation supports its insularity, coloured immigrants can only be acceptable if they spontaneously respect the particular sense of Englishness, acting, dressing, eating and talking as native-born Britons. They are expected to mimick their allotted roles, to become the mirror of a homogeneous England, and to enter and uphold the English order. Their particular histories (cultural, ethnic, racial and religious) have to be negated. Assimilation is their only way to avoid exclusion.

While the immigrants want to assimilate into English society by imitation, the middle-and lower-class English succumb to the mimicry of upper-class respectability in $\mathrm{Mr}$ Stone and the Knights Companion. The English characters for the most part are shallow mimics, lacking a genuine self to be falsified by posturing. Their role-playing comments on the insincerity and fraudulence built into the fabric of the metropolis. At the beginning of the novel, Margaret Springer is introduced by her unsuitably stagy dressing at the Tomlinsons' annual Christmas dinner party - "Mrs Springer was over fifty, striking in her garnets, a dark red dress of watered silk, cut low, the skirt draped, and a well-preserved goldembroidered Kashmir shawl" (Naipaul, 1963, p. 12). She establishes herself as a wit in an obvious display of theatricality - "her manner went contrary to her dress; it was not a masculinity she attempted, so much as an arch and studied unfemininity. Her deep voice recalled that of a celebrated actress, as did her delivery" (Naipaul, 1963, p. 12). Her statement that "the only flower I care about... is the cauliflower" (Naipaul, 1963, p. 13) greatly impresses Mr Stone. So Mr Stone does have some reason to expect that Margaret will provide him some intellectual and social stimulation. Upon marrying Mr Stone, however, Margaret discards her party manner and attaches "the greatest importance to her 
functions as a woman and a wife" (Naipaul, 1963, p. 46), until she appears to possess no true character of her own. She encourages Mr Stone to keep up and reinforce the empty routines of his former life: he becomes the Master to Miss Millington, and is cajoled into taking up gardening as a hobby. She also encourages him to undertake socially acceptable formalities, such as hosting a dinner party "which to a large extent recreated one of the Tomlinsons' dinner parties" (Naipaul, 1963, p. 47). The dull, meaningless dinner party at which wine is sipped like liqueur, women play music and sing, and men clown and jest is a pathetic imitation of the lifestyle of the upper class. Gwen entertains the guests by reciting a scene from The Importance of Being Earnest "in imitation of the celebrated actress, for the female" (Naipaul, 1963, p. 51), and the court scene from The Merchant of Venice, speaking rhetoric "as though it were everyday speech" (Naipaul, 1963, p. 52). Later, after Mr Stone's social eminence grows with his Knights Companion scheme, Margaret adjusts once again "as easily as she had always taken on new roles" (Naipaul, 1963, p. 87). She becomes the self-effacing wife "who encouraged and inspired her husband in his work" (Naipaul, 1963, p. 87). To keep up with her new status as a socialite, she collects a formal wardrobe, talks about making changes in the house or moving to the country after Mr Stone's retirement, and envisages dinner parties spreading out on the lawn in summer. Margaret's mimicry of the elite illustrates one of Naipaul's central themes-human beings always imitate their social superiors. The English are no exception as well. This echoes Naipaul's comment that "England is the least-educated country in Europe...it's so many people here, living at a very high material level, who have allowed their minds to go slack. The English bourgeoisie are mimicking their former roles. They express their soul by the color of their walls. They put dreadful pictures on their walls and stagger them" (Michener, 1997, p. 64).

\subsection{Superficial Cosmopolitan Consumption}

The upper-class respectability represented by the Tomlinsons and mimicked by Margaret and Gwen is actually superficial and fraudulent, because it assumes that access and openness to difference is only signalled by the consumption of cultural diversity and the attendant sense of sophistication. In the novel, Naipaul criticises this kind of elitist model of cosmopolitanism. The most successful cultural element in the spread of cosmopolitan ideals is what Calhoun (2002) calls "consumerist cosmopolitanism" (p. 105), enacted through the consumption of exotic cultures. Elaborating on the cosmopolitan construct, Douglas B. Holt highlights cosmopolitanism as a style of consumption that creates and maintains status distinctions between high-cultural-capital and low-cultural-capital consumers. The highcultural-capital consumers are said to possess a cosmopolitan habitus - a nexus of internalised and naturalised predispositions or proclivities toward cosmopolitan consumption practices that reflect a history of class-based socialisation. Holt's informants from "the upper tier of the middle-class - the highly educated, urbane New Class", for example, "express Cosmopolitan tastes even when they are not participating in the activities that they deem essential for that lifestyle" (Holt, 1997, p. 338-339). They gravitate toward exotic food and music, and are highly dissatisfied with the parochial cultural offerings of their own community. To the contrary, those informants possessing lower levels of cultural capital are not favourably inclined toward cultural fare deemed exotic; instead, they remain content in their local cultural milieu, and their consumption patterns are governed by strong preferences for the familiar and traditional. Ghassan Hage (1998) portrays cosmopolites as the elite pursuing refined consumption. Just as important as his/her urban(e) nature, the cosmopolite is a class figure and a white person, capable of consuming and appreciating "high quality" commodities and cultures, including "ethnic cultures" (p. 201).

But Calhoun (2002) cautions us: "Food, tourism, music, literature, and clothes are all easy faces of cosmopolitanism. They are indeed broadening, literally after a fashion, but they are not hard tests for the relationship between local solidarity and international civil society." (p. 105) Hannerz (2007) gives a similar warning:

Cosmopolitanism has two faces. In its aesthetic and intellectual dimensions, it can become a kind of consumer cosmopolitanism, a cosmopolitanism with a happy face, enjoying new cuisines, new musics, new literatures. Political cosmopolitanism is often a cosmopolitanism with a worried face, trying to come to grips with very large problems. We may suspect that it is entirely possible for people to be pleased with their experiences and their personal levels of connoisseurship in regard to cultural diversity without having any strong sense of civic and humanitarian responsibility transcending national borders. (p. 71)

Both Calhoun and Hannerz recognise that consumerist cosmopolitanism evades cultural openness to and ethical, political responsibility for others. Pnina Werbner (2008) summarises the elitist nature of cosmopolitanism as a consumer orientation as follows:

A cosmopolitan is, historically, an elect member of his or her society, familiar with the languages and high cultural products of European and American literature, art and music, able to converse about world history, philosophy, classical music, ballet, theatre and human rights. Culturally, such a cosmopolitan is an aesthetic consumer, living an elegant lifestyle, a connoisseur of good wine, haute cuisine and haute couture; a fashionable person with immaculate table manners, a sophisticated conversationalist and bon vivant, au fait with the latest novels and world current affairs. In other words, the 'true' cosmopolitan — unlike many anthropologists - is a man or woman of the world, but of a very specific world - that of Western, and especially European, elites. He or she is usually also a collector of world art. (p. 50)

Cosmopolitanism becomes a conglomeration of self-interested individuals whose primary aim is the personal satisfaction of an insatiable consumption of consumer goods. 
In Mr Stone and the Knights Companion, cosmopolitanism is revealed as the superficial aestheticisation and stylisation of metropolitan life through the depiction of the Tomlinsons' Christmas dinner parties. As Tony Tomlinson is "a figure of some importance in his local council" who never jokes about "his territorial decoration" such as his initial followed by the letters T.D., the couple's Christmas dinner parties increase "in severity and grandeur with the years" (Naipaul, 1963, p. 10-11) to match their superior status as the social elite. The dinner party at the beginning of novel shows that the Tomlinsons narrowly and superficially view their access to and consumption of exotic cultures in their everyday life as an indicator of their status-defining cosmopolitan orientation and aesthetics. The tarnished relics of an Austrian holiday that they turn into their "traditional decorations" (Naipaul, 1963, p. 15) appear to demonstrate the sophistication of their cultural interest. But the dinner party arrangements (candles, carved wood, manger scenes and pine trees), the floral decorations, and Grace Tomlinson's corsage that gain admiration from the guests turn out to be the result of a brief course at the Constance Spry school in St John's Wood. When the conversation among the guests comes around to the subject of films lately seen, the narrating voice informs the reader in a slightly ironic tone that Tony raises the discussion "to a more suitable intellectual level", which is "acknowledged as his prerogative and duty" (Naipaul, 1963, p. 13). Tony then announces that he watches Rififi "on the recommendation of a person of importance" (Naipaul, 1963, p. 13). This cosmopolitan aesthetics seems to differentiate him from the middle- and lower-class (for instance, Miss Millington who goes to the cinema to the cheap show for pensioners), but it is revealed as only posturing. He tries hard to attract his audience by "losing nothing of his suffering appearance, looking at none of them, fixing his eyes on some point in space as though drawing thoughts and words out of that point" (Naipaul, 1963, p. 13-14), whereas all the comment that he can produce is the repetition of "extraordinary" and "no dialogue". This scene discloses Tony's lack of the intellectual ability that a real cosmopolite possesses. The Tomlinsons imbricate conspicuous signifiers of their identity as cosmopolitans through the display of luxury. Their expenditure of resources and cursory consumption of cultures do not commit to a genuine cosmopolitan attitude or outlook. It is a fraudulent deployment of cosmopolitanism.

\subsection{Xenophobia underneath Cosmopolitan Openness}

While the Tomlinsons' seemingly cosmopolitan aesthetics and consumption are self-deceptive, the young PRO Whymper in the novel, "a man without a family, someone who belonged only to the city" (Naipaul, 1963, p. 109), is a trickster, adopting superficial cosmopolitan attitude and taste to conceal his xenophobia toward immigrants and to achieve social superiority. The urban deceit that Whymper embodies is identified by his house, furniture and food. His undistinguished terrace house with no garden is in Kilburn, but its location on the side of the High Road gives him a respectable Hampstead telephone number. He lives on the ground floor, renting out both the basement and other floors. His front room, decorated with two "perfunctorily modern" armchairs, a bullfighting poster, a jumbled bookcase of paperbacks, old newspapers and copies of Esquire, Time and The Spectator, and "a neat shelf of green Penguins" (Naipaul, 1963, p. 110), projects the image of urban sophistication. Inviting the Stones to dinner, Whymper displays his cosmopolitan consumption practice by serving them "cold sliced beef below a thick layer of finely chipped lettuce, cabbage, carrots, capsicums and garlic, all raw" with olive oil, Polish black bread that he thinks "ten times as good as our cotton wool" (Naipaul, 1963, p. 110-111), Greek retsina, biscuits with brie and camembert, and Turkish coffee. Ironically, he sniffs at the food in his plate "with mock disgust" and asks desperately for tomato ketchup, complaining: "Those dirty foreigners, eating all this garlic and grease." (Naipaul, 1963, p. 111) Later, Whymper's posturing cosmopolitan taste is further exposed by his illiberal attitude to race. He is driven into fury by "the sight of black men on the London streets" and spends the whole of one lunch-time walk "loudly counting" (Naipaul, 1963, p. 114) those whom he sees. Nevertheless, when Mr Stone quarrels with and insults a typist of Polish origin in the office in public, Whymper the xenophobe gives an exaggeratedly righteous performance defending the typist and criticising Mr Stone. Mr Stone cannot even believe Whymper is "the man who during those lunchtime walks had spoken with so much feeling about 'foreigners cluttering up the place"' (Naipaul, 1963, p. 128). Whymper's hypocritical adoption of an open, cosmopolitan attitude covers up his quintessential rejection of foreigners and wins him the advantage needed in the job market. At the end of the novel, Whymper takes all the credit for Mr Stone's original creation of the Knights Companion scheme to get a top executive position of publicity director in another company. Karl Miller (1977) comments that Naipaul "takes pleasure in the deals and treasons of Mr. Stone's circle, and makes of it a sort of sooty, strangulated, boring Miguel Street, with its own fragmented, none-too-organic community life” (p. 123).

\section{Conclusion}

In $\mathrm{Mr}$ Stone and the Knights Companion, Naipaul for the first time confronts and questions his long-held colonial fantasy about reassuring metropolitan purpose and desirable cosmopolitanism seen from afar. His depiction of the dull middle-class London life challenges metropolitan-centrism in cosmopolitanism. In his observation, the multiplication of cultural contacts and exchanges facilitated in the metropolis does not necessarily mean that the metropolitan locals exposed to it are pre-disposed toward cosmopolitan openness. The English, for example, in fear of the death of their local and national identities, shun immigrants, even in the face of the inevitable break-up of their homogeneous social world. Lacking the deeper curiosity about other cultures, they view the world through a local, parochial lens, even in their privileged travel that cosmopolitanism assumes to cultivate a sophisticated, worldly outlook. Using a detached, ironic tone, he criticises the English insularity as self-conscious and ignorant, and implies that people's open, cosmopolitan vision should be the key to cosmopolitanism. He discusses the allure and danger of cosmopolitanism: consumption of various cultural products and luxurious stylisation of metropolitan life are superficially understood as signals of access and openness to differences. From the perspective of an immigrant, Naipaul points out that under such a consumer orientation may actually lurk xenophobia toward others. 
In Mr Stone and the Knights Companion, London is steeped in illusions and shams all of its own, and the metropolitan respectability becomes a mere facade. Naipaul's sense of disillusionment can be best illustrated by the dream that he has not long after his return to London from his second journey to India recounted at the end of An Area of Darkness:

An oblong of stiff new cloth lay before me, and I had the knowledge that if only out of this I could cut a smaller oblong of specific measurements, a specific section of this cloth, then the cloth would begin to unravel of itself, and the unravelling would spread from the cloth to the table to the house to all matter, until the whole trick was undone. Those were the words that were with me as I flattened the cloth and studied it for the clues which I knew existed, which I desired above everything else to find, but which I knew I never would. (Naipaul, 2002, p. 289-290)

An analogous sense of London and England as a trick pervades Mr Stone and the Knights Companion, and many of Naipaul's subsequent novels (for example, The Mimic Men, A Bend in the River and The Enigma of Arrival) are suspended between such a colonial dream of perfection and the knowledge of its fraudulence.

\section{References}

Bridge, G. (2005). Reason in the city of difference: Pragmatism, communicative action and contemporary urbanism. London, England: Routledge.

Butler, T. (2003). Living in the bubble: Gentrification and its "others" in north London. Urban Studies, 40(12), 24692486.

Calhoun, C. (2002). The class consciousness of frequent travellers: Towards a critique of actually existing cosmopolitanism. In S. Vertovec \& R. Cohen (Eds.), Conceiving cosmopolitanism: Theory, context, and practice (pp. 86-109). Oxford, England: Oxford University Press.

Curtis, B., \& Pajaczkowska, C. (1994). Getting there: Travel, time and narrative. In G. Robertson, M. Mash, L. Tickner, J. Bird, B. Curtis, \& T. Putnam (Eds.), Travellers' tales: Narratives of home and displacement (pp. 199-215). London, England: Routledge.

Devadason, R. (2010). Cosmopolitanism, geographical imaginaries and belonging in north London. Urban Studies 47(14), 2945-2963.

Featherstone, M. (2002). Cosmopolis: An introduction. Theory, Culture \& Society 19(1-2), 1-16.

Hage, G. (1998). White nation: Fantasies of white supremacy in a multicultural society. Sydney, Australia: Pluto Press. Hannerz, U. (1990). Cosmopolitans and locals in world culture. Theory, Culture \& Society 7, 237-251.

Hannerz, U. (2007). Cosmopolitanism. In D. Nugent, \& J. Vincent (Eds.), A companion to the anthropology of politics (pp. 69-85). Oxford, England: Blackwell Publishing.

Hiebert, D. (2002). Cosmopolitanism at the local level: The development of transnational neighbourhoods. In S. Vertovec, \& R. Cohen (Eds.), Conceiving cosmopolitanism: Theory, context, and practice (pp. 209-223). Oxford, England: Oxford University Press.

Holt, D. B. (1997). Poststructuralist lifestyle analysis: Conceptualizing the social patterning of consumption in postmodernity. Journal of Consumer Research 23(4), 326-350.

Kanter, R. M. (1995). World class: Thriving locally in the global economy. New York: Simon \& Schuster.

King, B. (2003). V. S. Naipaul. Hampshire, England: Palgrave Macmillan.

McLeod, J. (2004). Postcolonial London: Rewriting the metropolis. London, England: Routledge.

Michener, C. (1997). The dark vision of V. S. Naipaul. In F. Jussawalla (Ed.), Conversations with V. S. Naipaul (pp. 6374). Jackson: University Press of Mississippi.

Miller, K. (1977). V. S. Naipaul and the new order. In R. D. Hamner (Ed.), Critical perspectives on V. S. Naipaul (pp. 111-125). Washington, D. C.: Three Continents Press.

Mustafa, F. (1995). V. S. Naipaul. Cambridge, England: Cambridge University Press.

Naipaul, V. S. (1963). Mr Stone and the knights companion. London, England: Andre Deutsch.

Naipaul, V. S. (1972). The overcrowded barracoon and other articles. London, England: Andre Deutsch.

Naipaul, V. S. (1985). Finding the centre. Harmondsworth, England: Penguin.

Naipaul, V. S. (2002). An area of darkness. London, England: Picador.

Nava, M. (2007). Visceral cosmopolitanism: Gender, culture and the normalisation of difference. Oxford, England: Berg.

Sandercock, L. (2006). Cosmopolitan urbanism: A love song to our mongrel cities. In J. Binnie, J. Holloway, S. Millington, \& C. Young (Eds.), Cosmopolitan urbanism (pp. 37-52). London, England: Routledge.

Thieme, J. (1984). Naipaul's English fable: Mr Stone and the knights companion. Modern Fiction Studies 30, $497-503$.

Vertovec, S, \& Cohen R. (2002). Introduction: Conceiving cosmopolitanism. In S. Vertovec, \& R. Cohen (Eds.), Conceiving cosmopolitanism: Theory, context, and practice (pp. 1-22). Oxford, England: Oxford University Press.

Werbner, P. (2008). The cosmopolitan encounter: Social anthropology and the kindness of strangers. In P. Werbner (Ed.), Anthropology and the new cosmopolitanism: Rooted, feminist and vernacular perspectives (pp. 47-68). Oxford, England: Berg. 